\title{
Efficacy of Compost and Some Biocontrol Agents in Controlling Cucumber White Mould Disease under Protected House Conditions
}

\author{
Gamal A. Ahmed ${ }^{1}$, Abeer H. Makhlouf ${ }^{2}$, Mohamed E. Selim ${ }^{2}$
}

\begin{abstract}
Five different Trichoderma isolates and three different bacterial genera (Serratia marcescens, Bacillus subtilis, Pseudomonas fluorescens) were used in the present study either separately or combined with compost to evaluate their biocontrol potential against Sclerotinia sclerotiorum either in vitro or in vivo. The results showed that all tested bioagents significantly affected the radial growth of the pathogen under laboratory conditions. The highest reduction $(61.85 \%)$ was detected with isolates $T$. asperellum followed by $T$. album which inhibited the radial growth by $60.74 \%$. The combination between $T$. viride $+T$. asperellum $+T$. album was the most effective in reducing disease severity during both seasons and increased yield up to $2.5 \mathrm{~kg} /$ plant. The influence of the tested biocontrol fungi and bacteria on essential lysis enzymes activity i.e. chitinase and Beta 1,3- glucanase was investigated. The results showed that both tested fungal and bacterial agents alone or combined with compost affected the activity of both enzymes positively. Similar findings were observed with aspect to three different oxidative enzymes activity i.e. peroxidase (PO), polyphenoloxidase (PPO) and phenylalanine ammonia lyase (PAL). The profiling of peroxidase activity was induced in treated cucumber plants. Moreover, the results revealed that treating cucumber plants with the investigated bioagents expressed new protein bands.
\end{abstract}

Key words: Trichoderma - biological control cucumber - white mould

\section{INTRODUCTION}

Cucumber (Cucumis sativus) is among the most widely grown vegetables all over the world (Paris et al, 2011). Sclerotinia sclerotiorum (Lib.) de Bary is a worldwide pathogen that can infect more than 400 plant species. This pathogen causes severe yield losses of many economic crops (Lu, 2003). Traditional management techniques such as crop rotation and cultural practice are not enough alone to stop the disease damage due to the host wide range and the ability of the pathogen to survive for a long time in the soil as sclerotia (Purdy 1979, Bolan and Hall 1994 and Elkahoui, et al, 2014). The low cost and eco-friendly application of biological control methods are gaining a high attention among all methods used to control plant diseases in general and Sclerotinia diseases particularly. Biocontrol depending on using either antagonistic fungi i.e. Trichoderma hamatum, Gliocladium virens, Trichoderma viride or bacteria, Pseudomonas fluorescens, found to be important in recent integrated pest management techniques that, can reduce the radial growth of the Sclerotinia sclerotiorum respectively (Abhiniti et al, 2011 and EL-Kafrawy 2008). Soil treatment with $T$. hamatum, $G$. virens or B. subtilis gave the maximum protection against the fungal infection followed by $T$. viride and $P$. fluorescens. Moreover, this treatment improved plant height and increased both flowers number and fruit yield. The biocontrol agents tested were nearly as effective as the fungicide Topsin. M. Helmy; 2016 also found that, Streptomyces $s p$., followed by $P$. flourescens and Bacillus subtilis significantly reduced mycelium growth of Sclerotinia sclerotiorum. Moreover, they significantly reduced the severity of the disease on cucumber plants as well as they enhanced the morphological and physiological parameters of treated plants compared with the control. Control of root rot and Sclerotinia diseases using biofungicides have been investigated in many types of researches (Li GQ, et al., 2003, Domenech, et al., 2006, Abdullah, et al., 2008, Berry, et al., 2010, Zeng, et al., 2012, and Rodriguez, et al., 2015). Oxidative enzymes such as peroxidase and polyphenol oxidase enhance the formation of lignin, while other oxidative phenols contribute in formation of defense barriers for reinforcing the cell structure (Avdiushko, et al., 1993). Chitinase and $\beta-1,3$ glucanase enzymes play a significant role in plant defense against fungi by hydrolyse their cell wall (Tian, et al., 2006 and Barilli, et al., 2010). Ahmed, et al., (2017) found that, integration between $T$. album $+B$. subtilis $+P s$. fluorescens and compost was the most effective treatment for reducing tomato Sclerotinia rot disease incidence and disease severity. As well as, this treatment increased the fruit weight per plant. Moreover, all treatments increased the phenols and flavonoids content in tomato plants. The addition of $10 \%$ compost to the soil significantly decreased the incidence of many diseases on different crops i.e.

DOI: 10.21608/asejaiqjsae.2021.178433

${ }^{1}$ Plant Pathol. Dept., Fac. Agric., Moshtohor, Benha University. Egypt.

${ }^{2}$ Agricultural botany Dept., Fac. Of Agric., Menoufiya University. Egypt.

Corresponding Author: G. A. Ahmed, Benha University,

Faculty of Agriculture - Moshtohor, Toukh, Kalyoubia, 13736, Egypt

E-mail: gamal.mohamed@fagr.bu.edu.eg

Received May 10, 2021, Accepted, June 13, 2021. 
Aphanomyces root rot of peas; Rhizoctonia root rot of bean, Sclerotinia drop of lettuce, Fusarium wilt of cucumber and phytophthora crown rot of pepper (Lumsden, et al., 1983).

The objective of current work is the controlling of cucumber Sclerotinia disease by the compatibility of compost in combination with bioagents in the greenhouse and protected house conditions in addition to estimating some biochemical parameters as a response of treating the plants.

\section{MATERIAL AND METHODS}

\section{1- Isolation and identification of the causal organism}

Diseased samples of cucumber plants showing Sclerotinia rot symptoms were collected from Qalyubia governorate (Moshtohor) and subjected to isolation trials. Sclerotinia was isolated from the lesions that appeared on diseased plants. The infected tissues were cut into small pieces, surface sterilized with sodium hypochlorite $(0.5 \%)$ for $2-3$ minutes, washed for several times with sterilized distilled water, dried between sterilized filter papers and transferred directly to the PDA medium in in the plate $9 \mathrm{~cm}$. The plates were incubated for $1-2$ days at $22 \pm 2^{\circ} \mathrm{C}$. The mycelium grown from the lesion pieces were transferred to potato dextrose agar (PDA) slants. The fungus was purified by the hyphal tip technique (Brown, 1924). The purified fungal isolates were identified according to Singh, (1982). PDA slants from the fungus were kept in refrigerator at $4^{\circ} \mathrm{C}$ for further experiments.

\section{2- Laboratory experiments}

Effect of antagonistic fungi on the growth of Sclerotinia sclerotiorum in vitro

Two discs ( $5 \mathrm{~mm}$ ) of 4 days old plain agar culture of antagonistic fungi; Tricoderma harzianum, T. viride, T. asperellum, T. album and T. lignorum (these isolates were obtained from plant pathology Dept., Fac. of Agric., Benha Univ. Egypt) and S. sclerotiorum were inoculated simultaneously each opposite the other $1 \mathrm{~cm}$ apart from the plate edge in individual plates $(\varnothing 9 \mathrm{~cm})$ contained $10 \mathrm{~mL}$ PDA medium. In the control treatment, each plate was inoculated with 1 disc of mycelial growth of a given isolate of $S$. sclerotiorum. Three plates in the middle were used for each treatment. All dishes were incubated at $22 \pm 2^{\circ} \mathrm{C}$ for 10 days. The percentage of the fungal growth reduction $(\mathrm{X})$ was calculated by using the following formula suggested (Abd-El-Moity, 1985).

$$
\mathrm{X}=\mathrm{G} 1-\mathrm{G} 2 \text { / G1 x } 100
$$

Where: $\mathrm{X}=$ fungal growth reduction.

$\mathrm{G} 1=$ linear growth of the pathogen inoculated alone.
$\mathrm{G} 2=$ linear growth of the pathogen inoculated against the antagonistic fungus.

Effect of antagonistic bacteria on growth of $S$. sclerotiorum in vitro

Studying the effect of antagonistic bacteria isolates (Serratia marcescens, Bacillus subtilis and Pseudomonas fluorescens) on the growth of $S$. sclerotiorum were conducted as follow; individual plates $(\varnothing 9 \mathrm{~cm})$ contained PDA medium were streaked at one side ( $1 \mathrm{~cm}$ apart from the plate edge) with a loop full of the antagonistic bacteria (48 hrs- old) grown on nutrient broth medium (NB) and incubated for $24 \mathrm{hrs}$ at $22^{\circ} \mathrm{C}$ then the same plate was inoculated at the opposite side $1 \mathrm{~cm}$ apart from the plate edge with $5 \mathrm{~mm}$ disc of 4 days-old plain agar culture of $S$. sclerotiorum. All plates were incubated at $22 \pm 2^{\circ} \mathrm{C}$ for 5 days (Maurhofer et al., 1995).

\section{3-Greenhouse experiments}

The inoculum of $S$. sclerotiorum was grown for two weeks on sand barley medium (3:1, w:w and 40\% water). Inoculum of $S$. sclerotiorum fungus was added to the potting soil at the rate of $3.0 \% \mathrm{w} / \mathrm{w}$, mixed thoroughly with the soil surface of each pot then watered and left for one week to ensure even distribution of the inoculum.

Effect of treating cucumber seedlings with some antagonistic on incidence with Sclerotinia mould disease

In this experiment, healthy cucumber seedlings of Barracuda hybrid f1 20- days-old (from Qaha nurseries, Qalyubia governorate) were inoculated. In each hole containing a cucumber plant, $30 \mathrm{ml}$ of individual spore suspension $\left(3 \times 10^{10}\right.$ spore/ $\left.\mathrm{mL}\right)$ of Trichoderma isolates and bacterial suspension $\left(10^{8}\right.$ cells $\left./ \mathrm{mL}\right)$ were drenched at the collar level. After one week the plants were transplanted into pots $(30 \mathrm{~cm})$ (Benchabane et al., 2000). After two months of inoculation and treatment, the disease severity was assessed using 0-5 scale where:

$0=$ no symptom, $1=0-25 \%$ of root browning, 2 $=26-50 \%$ of root browning, $3=51-75 \%$ of root browning, $4=76-100 \%$ of root browning, and $5=$ plant death according to Abdeljalil et al., (2016).

Disease Severity $\%=\Sigma(\mathrm{a} \times \mathrm{b}) / \mathrm{N}$ x K $\times 100$

Where: $a=$ Number of infected plants in each category.

$\mathrm{b}=$ Numerical value of each category.

$\mathrm{N}=$ Total number of examined plants.

$\mathrm{K}=$ The highest degree of infection category.

\section{Experiments of commercial protected house}

In two experiments (during 2017 and 2018) healthy cucumber transplants of Barracuda hybrid f1 were individually treated with $T$. viride, T. asperellum, $T$. 
album, T. viride, + T. asperellum, T. viride $+T$. album $T$. asperellum $+T$. album, $T$. viride $+T$. asperellum $+T$. album, Ps. fluorescens, B. subtilis and Ps. fluorescens + $B$. subtilis as pervious in greenhouse. Transplants were planted in pots $(30 \mathrm{~cm}$ in diameter) amended with mixture of soil and compost (was obtained from ElNile Company, Giza, Egypt) at 5\% or without compost. Soil was infested with inoculum of $S$. sclerotiorum fungus at the rate of $3.0 \% \mathrm{w} / \mathrm{w}$. Untreated transplants were used as a control. One transplant/pot and five replicates for each treatment were used. Disease Severity was recorded as mentioned before and average weight of fruits $(\mathrm{kg}) /$ plant was recorded.

\section{Determining of enzyme activities:}

Leaves sample of cucumber plants cv. Barracuda hybrid that treated with different treatments under the study in greenhouse were taken 30 days after transplanting. Leaf samples were ground with $0.2 \mathrm{M}$ Tris $\mathrm{HCl}$ buffer ( $\mathrm{pH}$ 7.8) containing $14 \mathrm{mM} \beta$ mercaptoethanol at the rate $1 / 3 \mathrm{w} / \mathrm{v}$. The extracts were centrifuged at $10,000 \mathrm{rpm}$ for $20 \mathrm{~min}$ at $4^{\circ} \mathrm{C}$. The supernatant layer was used to determine enzyme activities (Tuzun et al., 1989).

\section{Determination of Peroxidase (PO):}

Peroxidase activity was determined according to the method described by Allam and Hollis (1972) and Abdelsalam et al. (2020). Peroxidase activity was expressed as the increase in absorbance at $425 \mathrm{~nm} / \mathrm{gram}$ fresh weight $/ 15$ minutes.

\section{Determination of Polyphenoloxidase (PPO):}

The polyphenoloxidase activity was determined according to the method described by Matta and Dimond (1963). Polyphenoloxidase activity was expressed as the increase in absorbance at $420 \mathrm{~nm} / \mathrm{g}$ fresh weigh/min.

Determination of phenylalanine ammonia lyase (PAL):

The activity of PAL was determined according to the method described by Dickerson et al., (1984). PAL activity was expressed as $\mu \mathrm{mol}$ trans-cinnamic acid min ${ }^{1} \mathrm{~g}^{-1}$ protein.

\section{Determination of chitinase}

Determination of the activity of chitinase was carried out according to the method of Boller and Mauch, (1988). Chitinase activity was expressed as mM $\mathrm{N}$-acetylglucose amine equivalent released/g fresh weight tissue/60 minutes.

\section{Determination of $\beta-1,3-G l u c a n a s e:$}

Determination of the activity of the $\beta-1,3$-glucanase was carried out according to the method of Sun et al., 2006. $\beta$ 1-,3-glucanase was expressed as $\mathrm{mM}$ glucose

\section{6-Activity gel electrophoresis}

Sodium dodecyl sulfate-polyacrylamide gel electrophoresis (SDS-PAGE):

Eighty microliters ( $80 \mu \mathrm{L}$ of protein) of leaves sample were subjected to SDS-polyacrylamide gel electrophoresis was performed in $12 \%$ acrylamide slab gels following the system of Laemmli (1970) to identify their protein profiles. Gels were photographed scanned, analyzed using Gel Doc VILBER LOURMAT system.

\section{Peroxidase.}

Activity gel electrophoresis of peroxidase was carried out to study the expression pattern of different isoforms of PO with various treatments. For native anionic polyacrylamide gel electrophoresis according to the method of Sindhu et al., (1984).

\section{Statistical analysis}

Statistical analysis of experiments was done as given by Snedecor and Cochran (1989).

\section{RESULTS AND DISCUSSION}

\section{RESULTS}

1- Effect of some bioagents on the growth of $S$. sclerotiorum under in vitro conditions

It is clear from the data in Table $\mathbf{1}$ and Fig. $\mathbf{1}$ that all applied biological fungi reduced growth of $S$. sclerotiorum. Trichoderma asperellum was the most effective antagonistic fungus that inhibited the radial growth of the pathogen giving $(61.85 \%)$ followed by $T$. album which inhibited the radial growth by $60.74 \%$. However, T. harzianum and T. lignorum reduced the growth of $S$. sclerotiorum by 54.44 and $53.71 \%$, respectively.

Table 1. Effect of some bioagents on the growth of $S$. sclerotiorum in vitro

\begin{tabular}{lcc}
\hline \multicolumn{1}{c}{ Treatment } & $\begin{array}{c}\text { Mycelial growth } \\
(\mathbf{m m})\end{array}$ & Efficacy \% \\
\hline T. harzianum & 41.00 & 54.44 \\
T. viride & 37.67 & 58.15 \\
T. asperellum & 34.33 & 61.85 \\
T. album & 35.33 & 60.74 \\
T. lignorum & 41.67 & 53.71 \\
Control & 90 & 00.00 \\
L.S.D 0.05 & 2.85 & \\
\hline
\end{tabular}




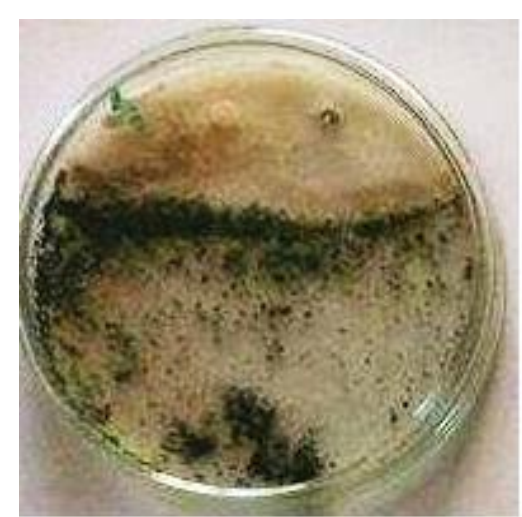

T. harzianum

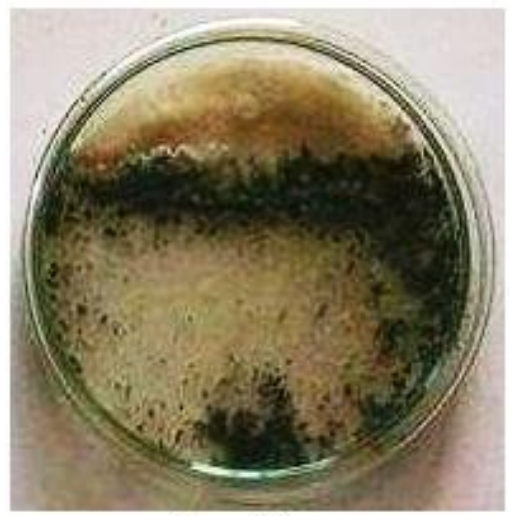

T. album

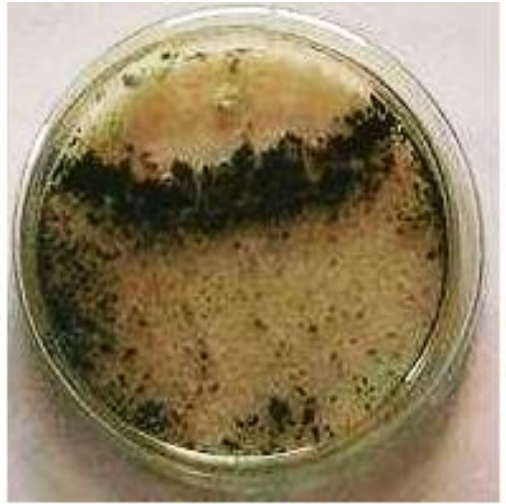

T. viride

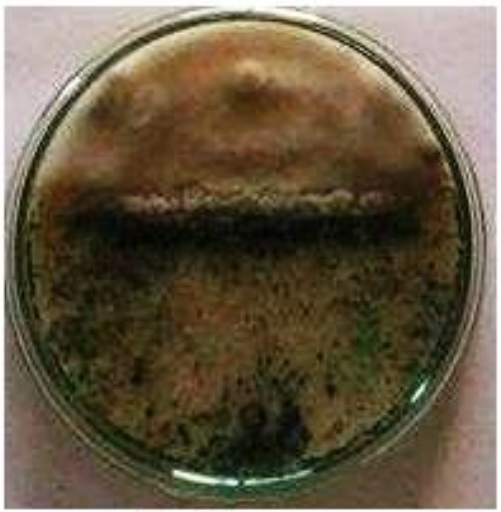

T. lignorum

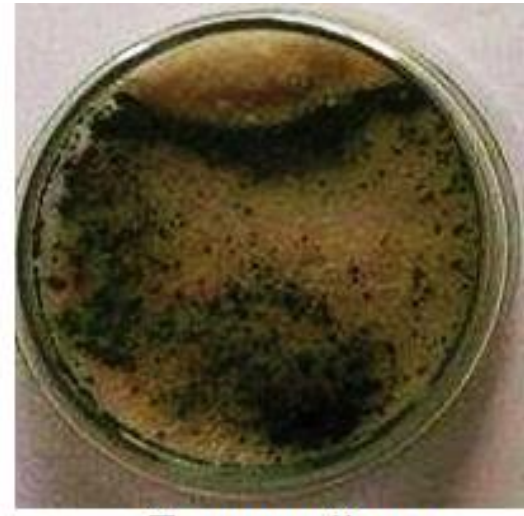

T. asperellum

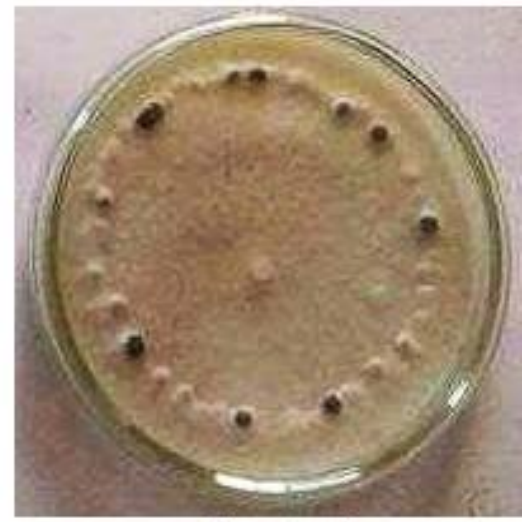

Control

Fig. 1. Effect of some bioagents on the growth of $S$. sclerotiorum under in vitro conditions

2. Effect of some antagonistic bacteria on the growth of $S$. sclerotiorum in vitro

Data in Table 2 show that all tested antagonistic bacteria reduced linear growth of $S$. sclerotiorum. Pseudomonas fluorescens was The most effective antagonistic bacteria which reduced the linear growth of the pathogen by $22.22 \%$

Table 2. Effect of some antagonistic bacteria on the growth of $S$. sclerotiorum in vitro

\begin{tabular}{lcc}
\hline \multicolumn{1}{c}{ Antagonist } & $\begin{array}{c}\text { Mycelial } \\
\text { growth }(\mathbf{m m})\end{array}$ & $\begin{array}{c}\text { Efficacy } \\
\mathbf{\%}\end{array}$ \\
\hline Serratia marcescens & 73.67 & 18.14 \\
Bacillus subtilis & 71.00 & 21.11 \\
Ps. fluorescens & 70.00 & 22.22 \\
Control & 90 & 0.00 \\
L.S.D 0.05 & 4.03 & \\
\hline
\end{tabular}

3. Effect of biological agents and compost alone or in combination on white mould severity of cucumber plants under greenhouse conditions

Data in Table 3 show that adding vegetarian compost to soil increased the activity of all antagonistic agent treatments than the individual treatment.

In this respect, T. album and Ps. fluorescens in compost-free soil reduced the disease severity by 85.26 and $83.13 \%$ respectively. Trichoderma asperellum and $T$. viride reduced the disease severity by 82.94 and $77.52 \%$ respectively in the same soil (compost free).

As for soil amended with compost results show that the highest reduction in disease severity was recorded by $T$. album and T. asperellum which recorded 94.19 and $93.02 \%$ respectively. Whereas, compost only reduced disease severity by $62.03 \%$. 
Table 3. Effect of biological agents and compost alone or in combination on white mould severity of cucumber plants under greenhouse conditions

\begin{tabular}{|c|c|c|c|c|}
\hline \multirow{2}{*}{ Treatment } & \multicolumn{2}{|c|}{ Without compost } & \multicolumn{2}{|c|}{ With compost } \\
\hline & Disease severity \% & $\%$ of Reduction & $\begin{array}{c}\text { Disease severity } \\
\%\end{array}$ & $\%$ of Reduction \\
\hline T. harzianum & 15.11 & 73.64 & 6.67 & 88.37 \\
\hline T. viride & 12.89 & 77.52 & 5.78 & 89.92 \\
\hline T. asperellum & 9.78 & 82.94 & 4.00 & 93.02 \\
\hline T. album & 8.45 & 85.26 & 3.33 & 94.19 \\
\hline T. lignorum & 15.11 & 73.64 & 6.22 & 89.15 \\
\hline Ps. fluorescens & 9.67 & 83.13 & 4.45 & 92.24 \\
\hline B. subtilis & 17.33 & 69.77 & 6.89 & 87.98 \\
\hline Serratia marcescen & 18.44 & 67.84 & 7.11 & 87.60 \\
\hline Compost & ----- & ----- & 21.77 & 62.03 \\
\hline Control & 57.33 & 0.00 & 57.33 & 0.00 \\
\hline L.S.D $0.05=$ & $\begin{array}{c}\text { Treatment } \\
4.87 \\
\end{array}$ & $\begin{array}{c}\text { Compost } \\
2.30 \\
\end{array}$ & \multicolumn{2}{|c|}{$\begin{array}{c}\text { Interaction } \\
5.97\end{array}$} \\
\hline
\end{tabular}

4- Effect of biological agents and compost alone or in combination on white mould severity of cucumber plants under protected house conditions

The data in Table 4 reveal that all tested treatments at both seasons (2017 and 2018) significantly reduced the percentage of white mould severity compared with the control. Adding compost to soil increased the efficacy of all treatments.

The combination of Trichoderma viride $+T$. asperellum $+T$. album was the most effective treatment (average 3.34\%) in aspect to reducing disease severity during both seasons and increased yield to $(2.5 \mathrm{~kg} / \mathrm{plant})$ followed by $T$. viride $+T$. album (average $3.67 \%$ and 2.38 $\mathrm{kg} / \mathrm{plant}$ ), T. asperellum + T. album (average $4 \%$ and 2.29 $\mathrm{kg} / \mathrm{plant}$ ) and $T$. viride $+T$. asperellum (average $4 \%$ and $2.27 \mathrm{~kg} / \mathrm{plant}$ ) compared with control (average $34.34 \%$ and $1.59 \mathrm{~kg} / \mathrm{plant}$ ). However, compost treatment alone was the least effective treatment at both seasons.

5- Effect of biological agents and compost alone or in combination on oxidative enzymes

Results presented in Table 5 indicate that all treatments increased the activity of peroxidase, polyphenol-oxidase and PAL enzymes compared with the untreated control. Generally, Trichoderma viride, $T$. asperellum and $T$. harzianum + Compost were superior for increasing the activity of peroxidase enzyme where they increased the activity of peroxidase by $213.70,189.45$ and $189.42 \%$, respectively. Meanwhile, Serratia marcescens + Compost was the lowest effective treatment, which increased the activity of peroxidase by $110.64 \%$.

Alternately, Ps. fluorescens + Compost followed by T. album and Bacillus subtilis + Compost were the most effective treatments and increased the activity of polyphenoloxidase by $56.67,50.63$ and $44.17 \%$ respectively. Whereas, compost alone increased the activity of peroxidase by $16.25 \%$ and was the lowest effective one.

As for PAL, Bacillus subtilis + Compost, $T$. album +Compost and Serratia marcescens were the most effective treatments and increased the activity of PAL by $255.36,157.21$ and $155.36 \%$ respectively. $T$. viride +Compost was the lowest effective one. 
Table 4. Effect of biological agents and compost alone or in combination on white mould and yield of cucumber plants under protected house conditions

\begin{tabular}{|c|c|c|c|c|c|c|c|c|c|c|c|c|}
\hline \multirow{3}{*}{ Treatment } & \multicolumn{4}{|c|}{ Disease severity \% } & \multicolumn{4}{|c|}{ Yield (kg/plant) } & \multicolumn{4}{|c|}{ Mean } \\
\hline & \multicolumn{2}{|c|}{2017} & \multicolumn{2}{|c|}{2018} & \multicolumn{2}{|c|}{2017} & \multicolumn{2}{|c|}{2018} & \multicolumn{2}{|c|}{$\begin{array}{c}\text { Disease } \\
\text { severity \% }\end{array}$} & \multicolumn{2}{|c|}{$\begin{array}{c}\text { Yield } \\
\text { (kg/plant) }\end{array}$} \\
\hline & W- & $\mathbf{W +}$ & W- & $\mathbf{W +}$ & W- & $\mathbf{W +}$ & W- & W+ & W- & $\mathbf{W +}$ & W- & W+ \\
\hline T. viride & 12.00 & 8.67 & 14.67 & 12.00 & 1.85 & 2.00 & 1.75 & 1.90 & 13.34 & 10.34 & 1.80 & 1.95 \\
\hline T. asperellum & 10.67 & 6.00 & 14.00 & 11.33 & 1.82 & 2.00 & 1.80 & 1.92 & 12.34 & 8.67 & 1.81 & 1.96 \\
\hline T. album & 10.00 & 4.67 & 12.67 & 10.67 & 1.90 & 2.10 & 1.86 & 2.00 & 11.34 & 7.67 & 1.88 & 2.05 \\
\hline $\begin{array}{l}\text { T. viride }+T \text {. } \\
\text { asperellum }\end{array}$ & 7.00 & 3.33 & 9.33 & 6.67 & 2.10 & 2.31 & 2.00 & 2.22 & 8.17 & 5.00 & 2.05 & 2.27 \\
\hline $\begin{array}{l}\text { T. viride }+T \text {. } \\
\text { album }\end{array}$ & 6.67 & 2.67 & 8.67 & 5.33 & 2.20 & 2.43 & 2.10 & 2.33 & 7.67 & 4.00 & 2.15 & 2.38 \\
\hline $\begin{array}{l}\text { T. asperellum }+T \text {. } \\
\text { album }\end{array}$ & 7.33 & 4.00 & 10.00 & 6.00 & 2.15 & 2.33 & 2.00 & 2.25 & 8.67 & 5.00 & 2.08 & 2.29 \\
\hline $\begin{array}{l}T . \text { viride }+T \\
\text { asperellum }+T \text {. } \\
\text { album }\end{array}$ & 5.33 & 2.00 & 8.00 & 4.67 & 2.34 & 2.56 & 2.25 & 2.43 & 6.67 & 3.34 & 2.30 & 2.50 \\
\hline Ps. fluorescens & 10.67 & 8.00 & 14.67 & 11.33 & 1.87 & 2.05 & 1.73 & 1.86 & 12.67 & 9.67 & 1.80 & 1.96 \\
\hline B. subtilis & 11.33 & 9.33 & 16.00 & 12.67 & 1.83 & 1.96 & 1.74 & 1.90 & 13.67 & 11.00 & 1.79 & 1.93 \\
\hline $\begin{array}{l}\text { Ps. fluorescens }+ \\
\text { B. subtilis }\end{array}$ & 8.00 & 4.67 & 10.67 & 7.33 & 1.94 & 2.23 & 1.92 & 2.10 & 9.34 & 6.00 & 1.93 & 2.17 \\
\hline Compost & ---- & 13.33 & ---- & 17.33 & ---- & 1.74 & ---- & 1.68 & ---- & 15.33 & ---- & 1.71 \\
\hline Control & 32.67 & ---- & 36.00 & ---- & 1.62 & ---- & 1.55 & ---- & 34.34 & ---- & 1.59 & ---- \\
\hline
\end{tabular}

$\mathrm{W}-=$ without compost $\quad \mathrm{W}+=$ with compost

\begin{tabular}{|c|c|c|c|c|}
\hline LSD $0.05=$ & & & & \\
\hline Treatment & 1.56 & 0.80 & $\begin{array}{ll}0.28 & 0.12\end{array}$ & 0.25 \\
\hline Interaction & 2.21 & 2.28 & 0.68 & 0.56 \\
\hline
\end{tabular}

Effect of biological agents and compost alone or in combination on lysis enzymes activity

The effect of biological agents and compost alone or in combination on the activity of chitinase and $\beta-1,3-$ glucanase is presented in Table 6. All the tested treatments increased chitinase activity. The highest activity of chitinase was induced by Bacillus subtilis and Ps. fluorescens + Compost (188.44 and 164.89\% increase respectively), followed by $T$. asperellum
149.33\% increase. The combination of Trichoderma viride + Compost was the lowest effective one, which increased the activity by $14.67 \%$.

As for $\beta$-1,3-glucanase, the highest increase was recorded by $T$. asperellum + compost (193.75\%) followed by Ps. fluorescens and T. viride (192.50 and $187.50 \%$. respectively). Meanwhile Serratia marcescens + compost induced the lowest increase $(8.44 \%)$. 
Table 5. Effect of biological agents and compost alone or in combination on oxidative enzymes

\begin{tabular}{|c|c|c|c|c|c|c|}
\hline \multirow[t]{2}{*}{ Treatment } & \multirow[t]{2}{*}{ PO } & \multirow[t]{2}{*}{ PPO } & \multirow[t]{2}{*}{ PAL } & \multicolumn{3}{|c|}{ Efficacy \% } \\
\hline & & & & PO & PPO & PAL \\
\hline T. harzianum & 51.25 & 5.31 & 314.90 & 121.27 & 24.17 & 102.79 \\
\hline T. viride & 61.07 & 7.07 & 257.12 & 213.70 & 40.42 & 65.58 \\
\hline T. asperellum & 55.46 & 4.88 & 341.62 & 189.45 & 20.21 & 120.00 \\
\hline T. album & 54.76 & 8.17 & 339.46 & 186.42 & 50.63 & 118.61 \\
\hline T. lignorum & 42.82 & 7.09 & 273.73 & 134.89 & 40.63 & 76.28 \\
\hline Ps. fluorescens & 46.68 & 6.41 & 366.18 & 151.55 & 34.38 & 135.82 \\
\hline Bacillus subtilis & 48.44 & 6.01 & 395.79 & 159.13 & 30.63 & 154.89 \\
\hline $\begin{array}{l}\text { Serratia } \\
\text { marcescens }\end{array}$ & 48.09 & 7.02 & 396.52 & 157.62 & 40.00 & 155.36 \\
\hline Compost & 49.84 & 4.46 & 260.73 & 165.20 & 16.25 & 67.91 \\
\hline $\begin{array}{l}\text { T. harzianum + } \\
\text { Compost }\end{array}$ & 55.46 & 4.79 & 208.01 & 189.42 & 19.38 & 33.96 \\
\hline $\begin{array}{l}\text { T. viride }+ \\
\text { Compost }\end{array}$ & 54.76 & 7.13 & 180.34 & 186.42 & 41.04 & 16.14 \\
\hline $\begin{array}{l}\text { T. asperellum + } \\
\text { Compost }\end{array}$ & 52.65 & 4.50 & 371.24 & 177.33 & 16.88 & 139.08 \\
\hline $\begin{array}{l}\text { T. album }+ \\
\text { Compost }\end{array}$ & 44.93 & 5.31 & 399.40 & 143.98 & 24.14 & 157.21 \\
\hline $\begin{array}{l}\text { T. lignorum + } \\
\text { Compost }\end{array}$ & 47.39 & 4.52 & 225.34 & 154.60 & 16.88 & 45.12 \\
\hline $\begin{array}{l}\text { Ps. fluorescens }+ \\
\text { Compost }\end{array}$ & 46.68 & 8.82 & 228.23 & 151.55 & 56.67 & 46.98 \\
\hline $\begin{array}{l}\text { Bacillus subtilis + } \\
\text { Compost }\end{array}$ & 46.33 & 7.47 & 551.80 & 150.04 & 44.17 & 255.36 \\
\hline $\begin{array}{l}\overline{\text { Serratia }} \\
\text { marcescens }+ \\
\text { Compost }\end{array}$ & 37.21 & 4.50 & 283.84 & 110.64 & 16.67 & 82.79 \\
\hline Control & 11.58 & 2.70 & 155.28 & 0.00 & 0.00 & 0.00 \\
\hline
\end{tabular}

6. Effect of treating cucumber plants with some bioagents on PAGE of protein.

The results of SDS (PAGE) presented in Table 7 and demonstrated in Fig. 2 showed that fifteen protein bands with molecular weights ranging from 234.433 to 34.93 $\mathrm{kDa}$ are contained in cucumber plants. New protein bands are expressed as a result of treating cucumber plants with the bioagents. One band with $37.23 \mathrm{kDa}$ was appeared in plants treated with Ps. fluorescens, while absent in other treated plants. Moreover, the band with $159.517 \mathrm{kDa}$ appeared in plants treated with $T$. viride and absent in other treated plants. Also, a band with $34.93 \mathrm{kDa}$ appeared in plants cultivated in the soil amended with compost while absent in all treated plants. 
Table 6. Effect of biological agents and compost alone or in combination on lysis enzymes activity

\begin{tabular}{|c|c|c|c|c|}
\hline \multirow[t]{2}{*}{ Treatment } & \multirow[t]{2}{*}{ Chitinase } & \multirow{2}{*}{$\begin{array}{l}\text { Beta 1,3- } \\
\text { glucanase }\end{array}$} & \multicolumn{2}{|c|}{ Efficacy \% } \\
\hline & & & Chitinase & Beta 1,3-glucanase \\
\hline T. harzianum & 5.37 & 6.36 & 138.67 & 98.75 \\
\hline T. viride & 4.20 & 9.20 & 86.67 & 187.50 \\
\hline T. asperellum & 5.61 & 4.90 & 149.33 & 53.13 \\
\hline T. album & 3.71 & 6.91 & 64.89 & 115.94 \\
\hline T. lignorum & 4.29 & 5.15 & 90.67 & 60.94 \\
\hline Ps. fluorescens & 5.21 & 9.36 & 131.56 & 192.50 \\
\hline Bacillus subtilis & 6.49 & 6.59 & 188.44 & 105.94 \\
\hline Serratia marcescens & 2.93 & 4.17 & 30.22 & 30.31 \\
\hline Compost & 3.00 & 4.83 & 33.33 & 50.94 \\
\hline T. harzianum + Compost & 3.62 & 5.52 & 60.89 & 72.50 \\
\hline T. viride + Compost & 2.58 & 6.96 & 14.67 & 117.50 \\
\hline $\begin{array}{l}\text { T. asperellum + } \\
\text { Compost }\end{array}$ & 4.95 & 9.40 & 120.00 & 193.75 \\
\hline T. album + Compost & 3.63 & 4.83 & 61.33 & 50.94 \\
\hline T. lignorum + Compost & 3.65 & 5.14 & 62.22 & 60.63 \\
\hline $\begin{array}{l}\text { Ps. fluorescens }+ \\
\text { Compost }\end{array}$ & 5.96 & 8.52 & 164.89 & 166.25 \\
\hline $\begin{array}{l}\text { Bacillus subtilis + } \\
\text { Compost }\end{array}$ & 4.67 & 5.03 & 107.56 & 57.19 \\
\hline $\begin{array}{l}\text { Serratia marcescens + } \\
\text { Compost }\end{array}$ & 3.15 & 3.47 & 40.00 & 8.44 \\
\hline Control & 2.25 & 3.20 & 0.00 & 0.00 \\
\hline
\end{tabular}

Table 7. Molecular weights of fractionated protein profiles of cucumber leaves treated with selected treatments

\begin{tabular}{|c|c|c|c|c|c|c|c|c|}
\hline Band No & M.W KDa & T. viride & $\begin{array}{c}T . \\
\text { asperellum }\end{array}$ & T. album & $\begin{array}{c}\text { Bacillus } \\
\text { subtilis }\end{array}$ & $\begin{array}{c}\text { Ps. } \\
\text { fluorescens }\end{array}$ & Compost & Control \\
\hline 1 & 234.433 & + & + & + & + & + & + & + \\
\hline 2 & 159.517 & + & - & - & - & - & - & - \\
\hline 3 & 155.793 & - & + & + & + & + & + & + \\
\hline 4 & 133.304 & - & + & + & + & + & + & + \\
\hline 5 & 118.734 & - & - & + & - & - & - & - \\
\hline 6 & 112.191 & + & + & + & + & + & + & + \\
\hline 7 & 91.783 & - & - & - & - & - & - & - \\
\hline 8 & 85.101 & + & + & - & + & + & + & + \\
\hline 9 & 54.844 & + & + & + & + & + & + & + \\
\hline 10 & 50.017 & + & + & + & + & + & + & + \\
\hline 11 & 46.267 & + & + & + & + & + & + & + \\
\hline 12 & 41.996 & - & - & - & - & - & + & + \\
\hline 13 & 41.699 & + & + & + & + & + & + & + \\
\hline 14 & 37.23 & - & - & - & - & + & - & - \\
\hline 15 & 34.93 & - & - & - & - & - & + & - \\
\hline \multicolumn{2}{|c|}{ Total } & 8 & 9 & 9 & 9 & 10 & 11 & 10 \\
\hline
\end{tabular}

$+=$ bands appeared $\quad-=$ bands disappeared 


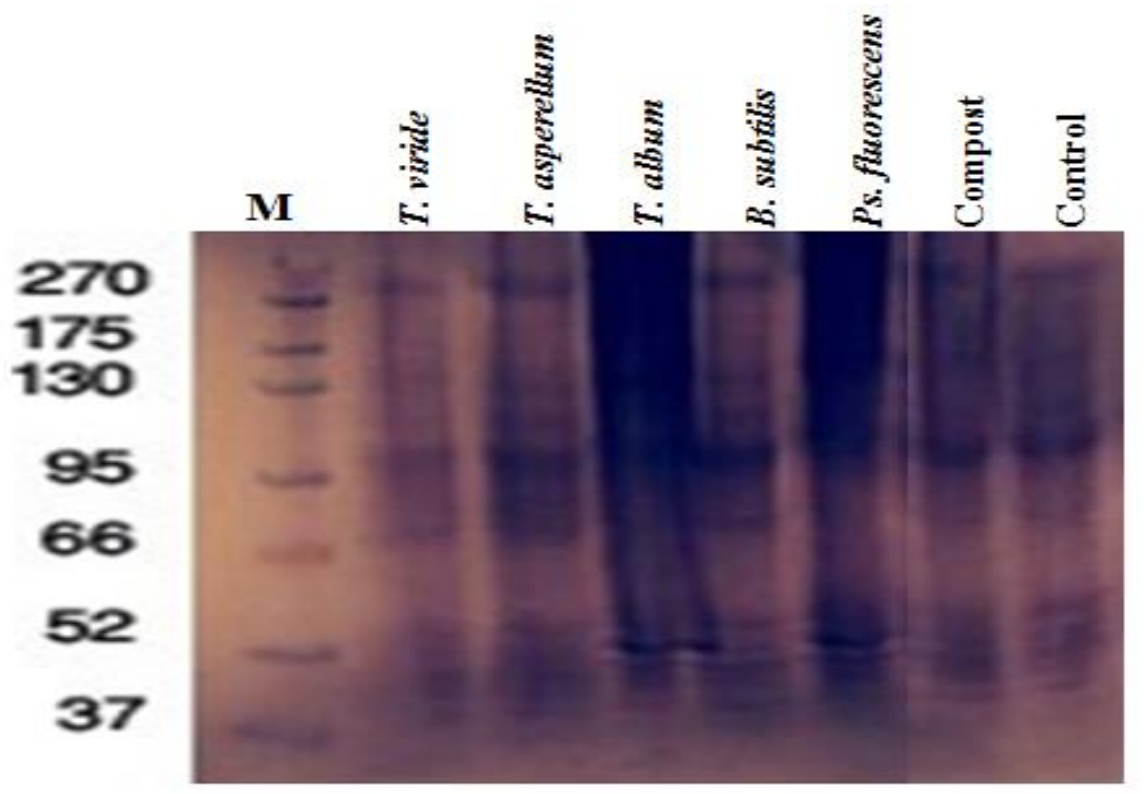

Fig. 2. Effect of treating cucumber plants with some bioagents on PAGE of protein Electrophoretic analysis of peroxidase isozymes

Table 8. Effect of bioagents and compost alone or in combination on Peroxidase isozymse activity

\begin{tabular}{ccccccccc}
\hline Peoxidase & $\begin{array}{c}\text { Relative } \\
\text { Mobility }\end{array}$ & $\begin{array}{c}\text { T. } \\
\text { viride }\end{array}$ & $\begin{array}{c}\text { T. } \\
\text { asperellum }\end{array}$ & $\begin{array}{c}\text { T. } \\
\text { album }\end{array}$ & $\begin{array}{c}\text { Bacillus } \\
\text { subtilis }\end{array}$ & $\begin{array}{c}\text { Ps. } \\
\text { fluorescens }\end{array}$ & Compost & Control \\
\hline Px 1 & 0.55 & $1^{++}$ & $1^{++}$ & $1^{+}$ & $1^{++}$ & $1^{+}$ & $1^{+}$ & $1^{+}$ \\
Px 2 & 0.65 & $1^{++}$ & $1^{++}$ & $1^{+}$ & $1^{++}$ & $1^{+}$ & $1^{+}$ & $1^{+}$ \\
Px 3 & 0.75 & $1^{++}$ & $1^{++}$ & $1^{++}$ & $1^{++}$ & $1^{+}$ & $1^{++}$ & $1^{++}$ \\
Px 4 & 0.85 & $1^{+}$ & $1^{+}$ & $1^{+}$ & $1^{+}$ & $\mathbf{1}^{-}$ & $\mathbf{1}^{-}$ & $\mathbf{1}^{-}$ \\
\hline
\end{tabular}

Peroxidase isozymes results of enzyme extract from cucumber plants treated with $T$. viride, T. asperellum, T. album, Ps. fluorescens, B. subtilis and Compost compared with control and planted in inoculated soil with S. sclerotiorum presented in Table 8 and Fig. 3 showed different PO patterns and induced the density of PO isozymes. Moreover, the increased density of the induced PO was found in T. viride, T. asperellum and $B$. subtilis compared with other treatments and control. Also, band 4 was low density in $P S$. fluorescens, compost and control treatments. 


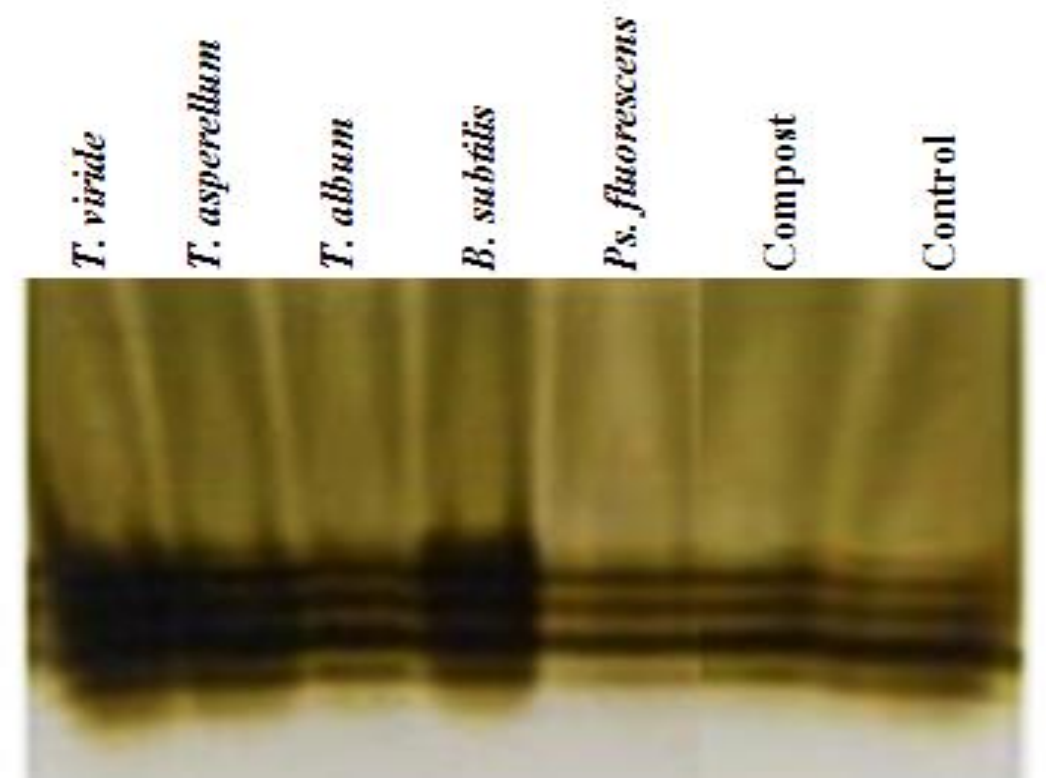

Fig. 3. Effect of bioagents and compost alone or in combination on Peroxidase isozymse

\section{DISCUSSION}

Trichoderma asperellum was the most effective antagonistic fungus and Ps. fluorescens was the best antagonistic bacteria inhibiting the radial growth of $S$. sclerotiorum in vitro. These results agree with those of Abdullah et al., (2008), Amer et al., (2010), Baharlouei et al., (2011) and Saraf et al., (2014). Trichoderma album was the most antagonistic fungus in inhibiting mycelial growth of $S$. sclerotiorum followed by Trichoderma lignorum. Bacillus subtilis was the best antagonistic bacteria in reducing growth of $S$. sclerotiorum followed by Pseudomonas fluorescens. Ahmed et al., (2017) reported that under greengouse conditions, integrated treatments of bioagents with compost were more effective than individual treatment. In the soil amended with compost, the highest decrease in disease severity was recorded by $T$. album and $T$. asperellum followed by $P$ s. fluorescens. Under protected house conditions all tested treatments at both seasons of 2017-2018, significantly decreased the percentage of white mould severity compared to the control. Adding compost to the soil increased the efficacy of all treatments. Trichoderma viride $+T$. asperellum $+T$. album was the most effective treatment resulted in reducing disease severity during both seasons followed by $T$. viride $+T$. album and $T$. asperellum $+T$. album. Compost individually was the least effective in both seasons. The current results are in harmony with those obtained by Ahmed et al., (2017). Under field conditions, adding compost to the soil before transplanting decreased the percentage of $S$. sclerotiorum infection and increased the yield. Integration of $T$. album $+B$. subtilis + Ps. fluorescens and compost was the most effective treatment and decreased disease incidence and severity of $S$. sclerotioum and also increased fruit weight per plant. The effect of organic amendments, suggests that both chemical and biological components of compostamended soils can contribute to disease suppression (Abbasi et al., 2002; Metcalf et al., 2004; Elkobrosy et al., 2020 and Youssef et al., 2020). Addition of 10\% compost to soil significantly decreased diseases such as Aphanomyces root rot of peas; Rhizoctonia root rot of bean, cotton, and radish, Sclcrotinia drop of lettuce, Fusarium wilt of cucumber and Phytophthora crown rot of pepper (Lumsden et al., 1983).

All treatments increased the activity of peroxidase, polyphenol-oxidase and PAL enzymes in comparison with the untreated control. Trichoderma viride, $T$. asperellum and $T$. harzianum + Compost were the superior for increasing the activity of the peroxidase enzyme respectively. Meanwhile, Ps. fluorescens + compost followed by T. album and Bacillus subtilis + compost were the most effective treatments and recorded the highest activity of polyphenoloxidase respectively. On the other hand, Bacillus subtilis + compost, T. album + compost and Serratia marcescens were the most effective in increasing the activity of PAL, respectively. The highest activity of chitinase was induced by Bacillus subtilis and Ps. fluorescens + Compost and $T$. asperellum respectively. Meanwhile, the highest increase of $\beta$-1,3-glucanase was recorded by 
T. asperellum + Compost followed by Ps. fluorescens and $T$. viride respectively. The profiling of peroxidase isoenzymes was induced in treated cucumber plants. Results of SDS (PAGE) of protein showed that 15 protein bands with molecular weights ranging from 234.433 to $34.93 \mathrm{kDa}$ were contained in cucumber plants. New protein bands were expressed as a result of treating cucumber plants with the bioagents. One band with $37.23 \mathrm{kDa}$ was appeared in plants treated with $P s$. fluorescens, while absent in other treated plants. Band with $159.517 \mathrm{kDa}$ appeared in plants treated with $T$. viride but was absent in the other treated plants. A band with $34.93 \mathrm{kDa}$ appeared in plants cultivated in soil amended with compost while absent in all treated plants. These results are in harmony with those recorded by Ahmed and El-Sisi (2020). Ahmed et al., (2017), found that, treating tomato plants with bioagents increased the activities of Peroxidase (PO), Polyphenoloxidase (PPO), Chitinase and $\beta-1,3$ glucanase enzymes in leaves of plants. Also, they reported that adding compost to the soil increased the effectiveness of bioagents. Ahmed, (2016) found that, treating bean seeds with bioagents caused considerable increase in the activities of peroxidase, polyphenol oxidase, chitinase and $\beta$-1,3-glucanase enzymes that play a significant role in plant defense mechanisms against pathogens infection. Results indicated that an increase in activity of the treated snap bean enzymatic activity of treated the snap bean plants. Oxidative enzymes such as peroxidase and polyphenol oxidase enhance formation of lignin, while other oxidative phenols contribute in formation of defence barriers for reinforcing the cell structure (Avdiushko et al., 1993). Chitinase and $\beta-1,3$ glucanase enzymes play a significant role in plant defense against fungi by hydrolysing their cell wall (Barilli et al., 2010).

\section{CONCLUSIONS}

Based on obtained results from the current study, both tested bio control agents i.e. Trichoderma isolates and bacterial strains were able individuality or in combination to affect negatively the development of Sclerotinia sclerotiuorum fungus on cucumber plants and led to significant increase in yield. Compost addition enhanced the biocontrol activity of used biological control agents.

\section{REFERENCES}

Abbasi, P. A., J.Al-Dahmani, F.Sahin, H. A. J. Hoitink and S. A. Miller. 2002. Effect of compost amendments on disease severity and yield of tomato in conventional and organic production systems. Plant disease. 86(2):156-161.

Abdelsalam, N. R., H. M.Ali, M. Z.Salem and H. E. El-Wakil. 2020. Quantitative and Qualitative Genetic Studies of Some Acacia Species Grown in Egypt. Plants. 9(2): 243.
Abdeljalil, N.Ouhaibi-Ben, J.Vallance, J.Gerbore, P. Rey and M.Daami-Remadi. 2016. Bio-suppression of Sclerotinia stem rot of tomato and biostimulation of plant growth using tomato-associated rhizobacteria. J Plant Pathol Microbiol. 7(331):2.

Abd-El-Moity, T.H. 1985. Effect of single and mixture of Trichoderma harzianum isolates on controlling three different soils -borne pathogens. Egypt. J. Microbiol. 111-120.

Abdullah, M.T., Y.Nida, N.Y. Ali and P.Suleman. 2008. Biological control of Sclerotinia sclerotiorum (Lib.) de Bary with Trichoderma harzianum and Bacillus amyloliquefaciens. Crop Protection. 27:1354- 1359.

Abhiniti. M., A.Tripti and P.C. Trivedi. 2011. In vitro efficacy of various fungal and bacterial antagonists against Rhizoctonia solani, causal Agent of Disease in Capsicum Annuum L. International J. of Pharma and Bio Sci. 2 (3): 288-292.

Ahmed, G.A. 2016. Efficiency of some antioxidants and bioagents in controlling Rhizoctonia damping-off of snap bean. Middle East J. of Applied Sci. 6(4): 748-758.

Ahmed, G. A. and A. A. Elsisi. 2020. Efficacy of compost and some essential oils alone or in combination in controlling cucumber white mould disease under protected house conditions. J. of Plant Protection and Pathology, Mansoura Univ. 11 (6):291-297.

Ahmed, G.A., A.M.M.Mahdy, R.N. Fawzy and N.A. Gomaa. 2017. Integrated management of tomato sclerotinia rot disease by using the combined treatments between compost, bioagents and some commercial biocides. Benha J. of Applied Sci. 2 (1):9-22.

Allam, A.I. and J.P. Hollis. 1972. Sulfide inhibition of oxidase in rice roots. Phytopathology. 62: 634-639.

Amer, M.A. I.I.A. Abou elseoud, M.R. Rasmy and M.M. Khater. 2010. Effects of a mycorrhiza fungi, bacteria, and yeast as biological control of Sclerotinia sclerotiorum on the growth of common bean (Phaseolus vulgaris L.). Alexandria sci. exchange j. 31(4): 339-352.

Avdiushko, S.A., X.S. Ye and J. Kuc. 1993. Detection of several enzymatic activities in leaf prints of cucumber plants. Physiol. and Mol. Plant Pathol. 42: 441-454.

Baharlouei, A., G.R. Sharifi-Sirchi and G.H.S. Bonjar. 2011. Biological control of Sclerotinia sclerotiorum (oilseed rape isolate) by an effective antagonist Streptomyces. African J. of Biotechnology. 10(30): 5785-5794.

Barilli, E., E.Prats and D.Rubiales. 2010. Benzothiadiazole and BABA improve resistance to Uromyces pisi (Pers.) Wint. In Pisum sativum L. with an enhancement of enzymatic activities and total phenolic content. Eur. J. Plant Pathol. 128: 483-493.

Berry, C., W.G.D.Fernando, P.C. Loewen and T.R.Kievit. 2010. Lipopeptides are essential for Pseudomonas sp. DF41 biocontrol of Sclerotinia Sclerotiorum. Biol Control. 55: 211-218.

Bolan, G.J. and R. Hall. 1994. Index of plant hosts of Sclerotinia sclerotiorum. Can J Plant Pathol. 16: 93108. 
Boller, T and F. Mauch. 1988. Chitinase from Phaseolus vulguris, leaves". Meth. Enzymol. 161: 479 - 484.

Brown, W. 1924. Two mycological methods: a method of isolating single strains of fungi by cutting out a hyphal tip. Ann Bot. 38: 402-404.

Dickerson, D.P., S.F.Pascholati, A.E.Hagerman, L.G.Butler and R.L. Nicholson. 1984. Phenylalanin ammonia-lyase and hydroxy cinnamate: CoA ligase in maize mesocotyls inoculated with Helminthosporium carbonum. Physiol Plant Pathol. 25:111-123.

Domenech, J., M.S.Reddy, J.W.Kloepper, B.Ramos and J. Gutierrez-Manero. 2006. Combined application of the biological product LS213 with Bacillus, Pseudomonas or Chryseobacterium for growth promotion and biological control of soil-borne diseases in pepper and tomato. BioControl. 51: 245258.

Elkafrawy, A. 2008. Biological control of white rot of cucumber caused by Sclerotinia sclerotiorum under greenhouse conditions. J. of Agricultural Research. 86(2):427-439.

Elkahoui, S., N.Djebali, I.Karkouch, A.Hadj Ibrahim and L. Kalai. 2014. Mass spectrometry identification of antifungal lipopeptides from Bacillus sp. BCLRB2 against Rhizoctonia solani and Sclerotinia sclerotiorum. Appl Biochem Microbiol. 50: 161-165.

Elkobrosy, D. H., D. G.Aseel, N. R.Abdelsalam, M. A.ElSaedy, S. Shama and E. E. Hafez. 2020. the effect of cyst nematode (globodera rostochiensis) isolate ddh1 on gene expression in systemic leaves of potato plant. J. of microbiology, Biotechnology and Food Sci. 10(1):9397.

Helmy, G.K. 2016. Screening Potential of Some Bacterial Species and Trichoderma hrzianum Against Sclerotinia sclerotiorum on Cucumber. J. Plant Prot. and Path., Mansoura Univ. 7 (12): 506-872,2016

Laemmli, U.K. 1970. Cleavage of structural proteins during the assembly of the head of bacteriophage T4. Nature. 227: 680-685.

Li, G.Q., H.C.Huang and S.N. Acharya. 2003. Antagonism and biocontrol potential of Ulocladium atrum on Sclerotinia sclerotiorum. Biol Control. 28: 11-18.

Lu, G. 2003. Engineering Sclerotinia Sclerotiorum resistance in oilseed crop. African J. of Biotechnolog. 2(12): 509516.

Lumsden, R.D., J.A. Lewis and P.D. Millner. 1983. Effect of composted sewage sludge on several soilborne pathogens and diseases. Phytopathology. 73: 1543-1548.

Matta, A. and A.E. Dimond. 1963. Symptoms of Fusarium wilt in relation to quantity of Fungus and enzyme activity in tomato stems. Phytopathology. 53: 574-587.

Maurhofer, M., C.Keel, D.Haas and G.De'fago. 1995. Influence of plant species on disease suppression by
Pseudomonas fluorescens strain CHA0 with enhanced antibiotic production. Plant Pathol. 44:40-50.

Metcalf, D.A., J.J.C. Dennis and C.R. Wilson. 2004. Effect of inoculum density of Sclerotium cepivorum on the ability of Trichoderma koningii to suppress white rot of onion. Plant Disease. 88: 287-291.

Paris, H.S., M. Daunay and J. Janick. 2011. Occidental diffusion of cucumber (Cucumis sativus) 500-1300 CE: two routes to Europe. Annals of Botany. 1:10.

Purdy, L.H. 1979. Sclerotinia sclerotiorum: History, diseases and symptomatology, host range, geographic distribution, and impact. Phytopathology. 69: 875880.

Rodriguez, M.A., C.Rothen, T.E.Lo, G.M.Cabrera and A.M. Godeas. 2015. Suppressive soil against Sclerotinia sclerotiorum as a source of potential biocontrol agents: selection and evaluation of Clonostachys rosea BAFC1646. Biocontrol Sci Technol. 25: 1388-1409.

Saraf, M., U. Pandya and A. Thakkar. 2014. Role of allelochemicals in plant growth promoting rhizobacteria for biocontrol of phytopathogens. Microbiol. Res. 169: 1829.

Sindhu, J.S., S.Ravi and J. L. Minocha. 1984. Peroxidase isozyme patterns in primary trisomics of pearl millet. Theoretical and Applied Genetics.68:179-182.

Singh, R.S. 1982. Plant Pathogens "the fungi" Oxford and IBH Publishing Co. New Delhi, Bombay Calcuta. pp: 443.

Snedecor, G.W. and W. G. Cochran. 1989. Statistical Methods, 8th Edition, Iowa State University Press. Ames.

Sun, H., J.Yang, C. Lin, X. Huang, R.Xing and K.Q. Zhang. 2006. Purification and properties of a $\beta$-1,3-glucanase from Chaetomium sp. that is involved in mycoparasitism. Biotechnology Letters. 28:131-135.

Tian, S., Y.Wan, G. Qin and Y.Xu. 2006. Induction of defense responses against Alternaria rot by different elicitors in harvested pear fruit. Applied Microbiol.Biotechnol. 70:729-734.

Tuzun, S., M.N.Rao, U.Vogli, C.L. Schardl and J.A. KU. 1989. Induced systemic resistance to blue mold, early induction and accumulation of $\mathrm{B}, 1,3$-gluconases chitinases and other pathogenesis - related proteins (bproteins) in immunized tobacco. Phytopathology.79:979983.

Youssef, N. H., A. A.Al-Huqail, H. M. Ali, N. R.Abdelsalam and M. A. Sabra. 2020. The role of Serendipita indica and Lactobacilli mixtures on mitigating mycotoxins and heavy metals' risks of contaminated sewage sludge and its composts. Scientific Reports. 10(1), 1-13.

Zeng, W., W.Kirk and J. Hao. 2012. Field management of Sclerotinia stem rot of soybean using biological control agents. Biological Control. 60(2): 141-147. 
الملخص العربي

فعالية السماد العضوي (الكمبوست) وبعض عوامل المكافحة الحيوية في مكافحة مرض العفن الابيض في الخيار تحت ظروف البيوت المحمية

جمال عاشور أحمد، عبير حدي مخلوف و محمد علوي سليم

نبات. تم دراسة تأثير البكتيريا والفطريات المختبرة على نثاط

إنزيمات التحلل الأساسية مثل الكيتينز وبيتا 1، ب-جلوكاينيز. أظهرت النتائج أن كلا من العوامل الفطرية والبكتيرية

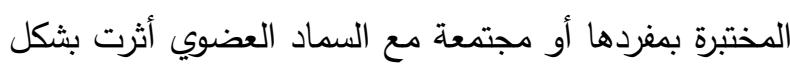

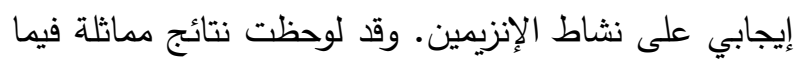
يتعلق بنشاط ثلاثة إنزيمات مضاده للاكسده مختلفة مثل

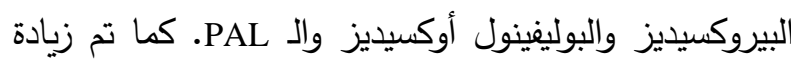

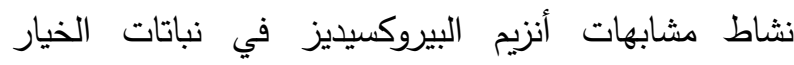

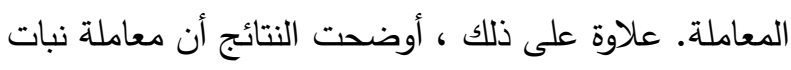
الخيار بالعوامل الحيوية ادي الي ظهور حزم بروتينية جديدة.
تم استخدام خمسة أنواع مختلفة من فطر Trichoderma وثلاثة أجناس بكتيرية مختلفة هي ( Serratia marcescens، إما بشكل المكل (Pseudomona fluorescens ،Bacillus subtilis منفصل أو مع السماد العضوي لتثييم إمكانات المكافحة

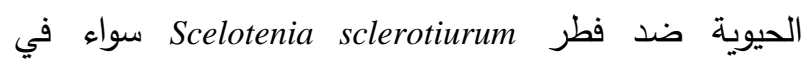
المعل أو الصوبة. أظهرت النتائج أن جميع العوامل الحيوية

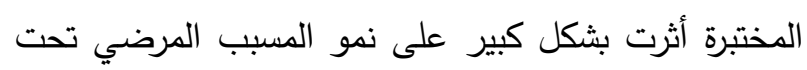

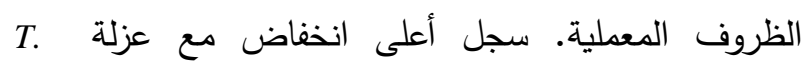

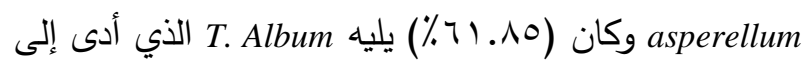

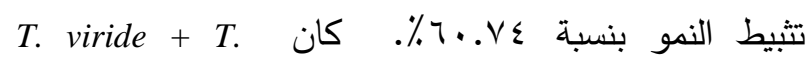
asperellum + T. Album

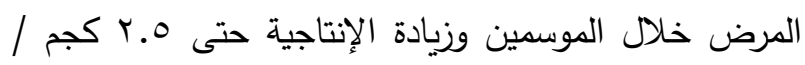

